\title{
Speech Characteristics of Indonesian Caregivers Towards Elderly in Japan
}

\author{
Putu Dewi Merlyna \\ Linguistics Postgraduate Program \\ Udayana University \\ Indonesia \\ dewimerlyna@gmail.com \\ Made Budiarsa \\ Faculty of Arts, \\ Udayana University \\ Indonesia \\ made_budiarsa@yahoo.com
}

\author{
N.L. Sutjiati Beratha \\ Faculty of Arts, \\ Udayana University \\ Indonesia \\ Sutjiati59@gmail.com \\ I Nengah Sudipa \\ Faculty of Arts \\ Udayana University \\ Indonesia \\ nengahsudipa@yahoo.com
}

\begin{abstract}
This study aims to find out the speech characteristics used by caregiver when serving elderly patients. The usage of appropriate speech related to selection of appropriate vocabulary and language. And also related to the use of speech level in Japanese, whether using keigo or futsuukei. This study also focus on speech affect the comfort of the elderly patient. This study was conducted some nursing home in Japan. Random sampling method was applied to select the research location. The subject of this research is Indonesian caregiver spreaded in 6 nursing home, the elderly, and the management of the hospital. Methods in collecting the data are observation, questionnaires, and interviews. The results of this study is a collection of specific vocabulary in the field of nursing, as well as the characteristic of caregiver's Japanese utterances understand from the type of speech and the choice of vocabulary used when speaking.
\end{abstract}

Keywords—speech; politeness strategy; Indonesian caregiver; elderly

\section{INTRODUCTION}

Japanese is commonly known as a language that has a speech level in terms of linguistics. Many Japanese researchers and linguists mention that in Japanese there are two levels of speech that is the use of respectful language (keigo) and non-formal language (futsuukei). Honorific language is divided into three types: sonkeigo, kenjougo, and teineigo (Kikuchi, 1996; Suzuki, 1998; Iori Isao, 2001; Kabaya, 2010; Kaneko, 2010; Rahayu, 2017). The use of honorific language in a speech indicates that the speaker appreciates his or her partners in an asymmetrical position with the speaker. Speakers make themselves lower than their partners or hearers. In addition, the Japanese speech community is a society with social stratification (social class) similar to the Javanese speech community (Fasold, 1990; Geertz, 1981; Hudson, 1982; Rahayu, 2014), Balinese (Suayra ,2001), Sundanese (Anderson, 1997), Sasak (Austin and Northofer, 2000), Madurese (Davies, 2010), and Korean.

This study deals with a particular group of language users, they are elderly caregivers. It is associated with language behavior in a particular place, in this case is the workplace of the nurse. This study is to find out how to communicate between the caregiver (CG) and the elderly (EP). This finding is different from Backhaus (2009) who examined politeness strategy of caregivers to the elderly at the nursing home in Tokyo and Germany. Backhaus (2009) found two kind of strategy. They were joke and prise which related to FTA (Brown \& Levinson, 1978).

The problems discussed is the speech used by Indonesian caregiver which is associated with the appropriate vocabulary selection. It is to find out the form of vocabularry mapping, which include. specific vocabulary and speech related to the caregiver's domain of work in the nursing home.

\section{LITERATURE REVIEW}

\section{A. Pragmatics Theory}

Pragmatic is a branch of linguistics that examines the meaning, meaning or force of a speech by the speaker (speaker's meaning). This science was born because of many speech phenomena in daily life that is communicative but can not be explained linguistically (Levinson, 1991, p. 9). The definition of the pragmatic (goyouron) according to the Japanese linguist's point of view (Hayashi, 1990, p. 171) is the theoretical study of the relationship of language to the scene or situation used by that language. Thus, it can be concluded that pragmatics examines the form of interpretation of speakers in a context of the conversations conducted by the speaker. It takes various considerations to determine the meaning of a speech act. The elements that become the consideration are the speakers, hearers, place, time, and under what circumstances speech acts that occur. In pragmatics theory there are concept of speech acts, maxim, politeness, implicature, etc. In this study, speech acts concept used to analysed the data.

\section{B. Speech Acts ( 言語行動 'gengokoudou') of Indonesian Caregiver}

The term of speech actsemerges from the assumption that the minimum unit of human communication is not a sentence but a particular performance of speech acts such as giving 
statements, asking questions, giving orders, explaining, apologizing, and thanking. Searle (1976) mentioned it as illocutionary act.

In Japanese, speech act is called 言語行動 (gengokoudou). Hayashi (1990, p. 147) stated that; 言語行動は対人的伝達行

動である, which means speech acts are communication between humans.

Similar to Austin (1962), Hayashi (1990) has the same opinion that at every opportunity, the acts committed in producing a speech will consist of three types of speech acts. The three actions are the locutionary act (hatsuwakoui), illocutionary act (hatsuwanaikoui), and perlocutionary act (hatsuwakoui). Yule (1996) also supported the opinion that the action displayed by producing a speech will contain three interconnected acts, the first is the act of locution, the second is the illocution, and the last is the perlocution.

It was seen that the Indonesian caregiver's speech at nursing home in Japan from the preliminary data obtained, it was observed that caregivers used many direct speeches and few indirect speeches adapted to the context and circumstances of speech when speaking with elderly patients; using positive politeness strategy and negative politeness strategy alternately in an utterance.

\section{Sample data : VideoM2U00136 \\ Duration : 3 minutes 27 seconds (Minute 1) \\ Setting : Living Room.}

Context of

Situation

:Indonesian caregiver offering beverages to theelderly while resting in a living room, in the afternoon.

\section{IN:たけがわさん冷たいのいい？あたたかい？冷たい？お？}

Takegawa san, tsumetai no ii? Atatakai? Tsumetai? Ochawa? Takegawa san, do you want the cold one? Or the hot one? cold? The tea?

\section{:冷たいの Tsumetai no The cold one}

Analysis: from a fragment of dialogue between caregiver and the elderly above, it appears that caregiver chose direct speech with an interrogative sentence in form. The underlined section is a Japanese language with non-formal language (futsuukei), with a directive type of speech. The characteristic of the futsuukeiusage is the removalof the copula 'desu' at the end of the sentence. One form of a question sentence with a futsuukei form is a sentence closer with marker ' $n o$ ' or in the end of a sentence pronounced with a rising tone. In a fragment of the dialogue above, it can be observed that the caregiver's speech is not threatening the face of the heareror the elderly. It is marked by the response given by the elderly. So it can be said that the illocution of caregiver in the form of offering 'warm or cold' drinks, can be well received by the elderly, although caregivers use non-formal language (futsuukei) in the service to the elderly. Therefore, from the examples mentioned above, there are different social phenomena from those happened in Japan in common. Caregivers who are young person use nonformal language when communicating with the elderly. In other words there is a violation of Japanese language used by the Indonesian caregivers. Usually it is expressed in honorific language based on Japanese concept. When there is difference of age between caregiver and elderly (Kabaya, 2009).

In Japan, the position of a person determines the choice of language in the speech, with the selection of keigo 'honorific language' or the use of futsukei 'ordinary form'. Both selections use their own markers. . Based on the rule of using keigo, the form of sonkeigo is used to elevate verb or the position of the partners in communication, while kenjougo is used to degrade the condition or action O3 (Suzuki, 1998; Kamei, 2006; Kabaya, 2009). Besides, there are a variety of softness (teineigo) and the use of the ordinary form (futsuukei). The examples of the Indonesian caregivers' utterances can be observed below.

\section{METHOD}

The qualitative approach is used in this study, in the sense that all aspects and characteristics of relationships related to the politeness of the caregiver in using the Japanese language can be observed in depth and described in detail. This study was to find out the politeness of Japanese language used by Indonesian caregivers towards the elderly in Japan, as well as the management team of the nursing home. In this study there were 39 caregivers, 10 elderly people, and 4 people from the nursing home management team consisting of directors, deputy directors, unit leaders, and a doctor in the rehabilitation department. So the total number of the informants in this study are 53 people. Observations of this study focused more on nursing home, with different backgrounds such as in the living room, dining room, toilet, sleeping room, and bathroom. The data were wastaken throughout Japan. The nursing home chosen was done by using random sampling in some areas of Japan. The nursing home is located in the Okayama area (2 nursing homes), Chiba area, Kagawa area, Hyogo area, and Fukuoka area.

This study used two types of data, namely primary and secondary data. Data sources were divided into two namely:

a) Oral/verbal data source in the form of video recordings taken from the speech of Indonesian caregiver while communicating with theelderly patients; and

b) Nonverbal data source taken from the interaction or communication in the form of attitude or mimic shown by Indonesian caregivers and attitude and facial expression from the elderly patients as a form of their response.

Data collection techniques consisted of 1) observation technique, 2) recording technique, 3) note taking technique, 4) questionnaire technique, and 5) interview techniques. Triangulation of data used is triangulation of data source and method triangulation. The result of data analysis was presented by using in the formal and informal method. It was by presenting the result of the analysis by giving description and explanation symbols. 


\section{RESULT AND DISCUSSION}

A. Analysis of Indonesian Caregivers' Utterances to Elderly in Japan

Two examples below are samples of analysis of Japanese speech.

1) CG $\begin{aligned} & \frac{\text { :あついのがいい。 }}{\text { Atsui no ga ii. }} \\ & \text { Want the hot on } \\ \text { EP } & \text { :もけ あつい。 } \\ & \text { Mokeatsui. } \\ & \text { Very hot. } \\ \text { CG } & \text { :もけ あつい } \\ & \text { Mokeatsui. } \\ & \text { Very hot. }\end{aligned}$

The setting of conversation between the Indonesian caregiver with the elderly are as follows above..

Time : April 13, 2017

Theme : Offering Tea

Situation : Breakfast

Analysis : the utterances classified as direct speech in the form of interrogative sentence. By type, the utterance is a direct speech act because the utterance has the same mode and the meaning. In pragmatic concepts, the interrogative sentences used by caregivers do not always used in normative terms. The utterances have function to provide two options such as agree and disagree to the partner. Based on the marker, the underlined sentence is classified as futsuu because it does not removegimonshi ' $k a$ ' and copula 'desu'.

2) CG: : 寒い?
Samui?
Cold?
EP $\quad$ :........

CG：きむらさん、寒いですか？

Kimura san, samuidesuka?

Kimura san, do you want the cold one?

EP

:...........

CG :寒いわ

Samui wa

The cold one

EP : (nodded)

CG :じや、閉めますね

Jya, shimemasune

If it is so, I will close it for you.

The conversation settings between the Indonesian caregiver with the elderly in the data above are :

Time : April 14, 2017

Theme : Relaxing in the living room

Situation : Enjoying the afternoon snack
Analysis

: The type of the utterances above also includes an interrogative direct speech. Caregiver initially used the phrase "futsu" with the word 'samui'. Question mark refers to the rising intonation. This interrogative utterance is not responded by the elderly. Then the caregiver was asked again by using teinei form, that is by adding 'san' after the patients name and using 'desuka'. at the end of the sentence. When the type of interrogative utterance was expressed in the form of teinei and still did not get a response, eventually the caregiver used the form of futsuukei 'samuiwa'. In Japanese ,'wa' is the aitsuji placed at the end of the utterance as a marker of futsuukei form. Looking at the type of caregiver used in questioning, there is a diversion from futsuukei, to teinei, and back to futsuukei. The diversion from futsuukei to teinei is used by the caregiver to get a response, but at the end of the conversation infutsuu, the elderly nodded as a response (because it is said near the patient's ears). Therefore, it can be concluded that the transfer from regular form to teineidoes not affect the response of the elderly. This shows that the elderly can respond when the caregiver uses the futsuukei form, as long as it is done by approaching the patient's ear. Discussion

The result of this research shows that in daily communication between the caregivers and the elderly., the caregivers use direct speech in the form of interrogative sentence. The speech may contain two kinds of politeness at the same time. They are positive and negative politeness. The caregivers combine the polite form of 'sonkeigo' with the nonformal form of ' futsuukei' or vice verse. This finding is different from Backhaus (2009) who examined politeness strategy of caregivers to the elderly at the nursing home in Tokyo and Germany. Backhaus focused only on the strategy of politeness used by the caregivers and he found out two kinds of strategy. They were joke and prise which were related to FTA (Brown \& Levinson, 1978).

\section{V.CONCLUSION}

To show hospitality to the elderly, the caregivers use speech types which depend on the context of situation of the communication. In Japanese the speech levels chosen have their own varieties. Ordinary speech may switch to polite form, or vice versa.

\section{References}

Brown, P. and Levinson, S. C. (1978). Universals politeness phenomena. Cambridge: Cambridge University Press.

Brown, P. and Levinson, S. C. (1987). Politeness: some universals in language usage. Cambridge: Cambridge University Press. 
Ide, S. (1982). Japanese sociolinguistic: politeness and women's language. Lingua, 57 (2/54), pp. 357-358. Tokyo: North-Holland Publishing.

Ide, S. (1989). Formal form and dicernment: two neglected aspects of universalsof linguistic politeness. Multilingua, $8(2-3), 223-248$.

Kabaya, Hiroshi. et al. (2009). Keigohyougen. Tokyo: Taihuukan.

Kabaya, Hiroshi. et al. (2010). Keigokomyunikeeshon. Tokyo: Asakura.

Kaneko, Hiroyuki. (2014). Nihongo keigo toreeninggu. Tokyo: PT Ask.

Masato, Takiura. (2005). Nihon no keigoron. Japan: Taishukan.
Masato, Takiura. (2008). Poraitonesu nyuumon. Japan: Kenkyusha.

Nadar, F.X. (2009). Pragmatik \& penelitian pragmatik. Yogyakarta: Graha Ilmu.

Rahayu, T. (2013). Sistem dan fungsi tingkat tutur bahasa jepangdalam domain perkantoran. Disertasi. Universitas Sebelas Maret.

Scollon, R dan Scollon, Suzzane Wong. (1995). Intercultural communication: discourse approach. Cambridge: Blackwell.

Suzuki, Yukiko. (1998). Utsukushii keigo no manaa. Tokyo: Miryoku Bijitsu.

Yule, G. (1996). Pragmatics. New York: Oxford University Press. 